\section{Loyalitas Kreativitas \\ Aldi Masyarakat Kreatif}

\title{
PEMBERDAYAAN ZAKAT DAN WAKAF PRODUKTIF DALAM KAJIAN EKONOMI SYARIAH DAN HUKUM POSITIF DALAM MENINGKATKAN EKONOMI UMAT
}

\author{
Khotimatus Sadiyah,Wiwik Hasbiyah AN, Haryono,Sugeng Samiyono,R.Mohd Zamzami \\ Dosen Prodi Akuntansi Fakultas Ekonomi Universitas Pamulang \\ Email : dosen02232@unpam.ac.id,dosen00968@unpam.ac.id,dosen00961@unpam.ac.id, \\ dosen01271@unpam.ac.id, dosen01386@unpam.ac.id
}

\begin{abstract}
ABSTRAK
Pengabdian masyarakat ini berjudul "Pemberdayaan Zakat dan Wakaf Produktif dalam Kajian Ekonomi Syariah Dan Hukum Positif Dalam meningkatkan Ekonomi Umat" yang dilaksanakan di yayasan Al-Kamilah Sawangan Depok. Tujuan pengabdian ini adalah memberikan penyuluhan dan pendampingan terhadap Santriwan santriwati berkaitan dengan zakat dan wakaf produktif dan hukum positif dengan harapan dengan adanya penyuluhan tersebut pada Santriwan dan santriwati mampu memahami pengetahuan Agama dan pengetahuan hukum negara sehingga santriwan santriwati mampu menerapkan pemberdayaan zakat dan wakaf serta hukum positif bagi diri sendiri khususnya dan bagi masyarakat umumnya di yayasan Alkamilah guna meningkatkan ekonomi umat.

Metode pelaksanaan pengabdian ini adalah dengan penyuluhan dan pendampingan melalui rangkaian kegiatan identifikasi, pengkajian serta proses belajar yang terencana dengan 3 tahapan yaitu 1) Pengumpulan data, dengan memberikan data wawancara kepada Santriwan santriwati tentang pemahaman pemberdayaan zakat dan wakaf produktif dalam sudut kajian agama dan hukum 2). Pelatihan pemberdayaan zakat dan wakaf produktif dalam sudut kajian agama dan hukum dengan memberikan penyuluhan kepada Santriwan santriwati di yayasan Alkamilah. 3) Memberikan pendampingan Pelatihan tentang penghitungan zakat dan wakaf produktif dalam sudut kajian agama dan hukum. Untuk mendukung hal itu diperlukan sebuah rencana kegiatan diantaranya adalah tahap persiapan yaitu dengan menyiapkan semua peralatan yang dibutuhkan untuk melaksanan kegiatan pkm, studi literatur dan melakukan koordinasi dengan instansi lembaga yayasan terkait serta ketua yayasan khususnya. Tahap penentuan lokasi, yaitu dengan melakukan kunjungan ke lokasi. Tahap Perancangan implemnetasi dan pengawasan melalui pelatihan pemasaran syariah yang dilakukan oleh 5 orang dosen universitas pamulang fakultas ekonomi prodi akuntansi kepada santriwan santriwati di yayasan Alkamilah sawangan Depok

Kesimpulan dari pengabdian ini adalah peserta pengabdian sangat antusias terhadap pelatihan, hal ini ditunjukan dengan banyaknya antusiasme pertanyaan tentang zakat dan wakaf, baik penghitungan dan pengolahan zakat dan wakaf, serta kajian hukumnya.
\end{abstract}

\section{Kata kunci : Zakat, Wakaf, Agama, Hukum, Sosial, Ekonomi}

\section{ABSTRACT}

This community service is entitled "Empowerment of Zakat and Productive Waqf in Islamic Economic Studies and Positive Law in Improving the Economy of the Ummah" which was held at the Al-Kamilah Foundation, Sawangan Depok.The purpose of this service is to provide counseling and assistance to female students related to zakat and productive waqf and positive 


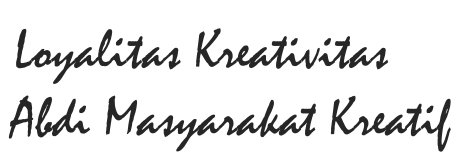

P-ISSN 2722-2101, E-ISSN 2722-4201

Program Studi Ekonomi Manajemen Universitas Pamulang Jurnal LOKABMAS Kreatif Vol.02,No.03.Nov2021Hal.8-13

Email:jurnalkreatif.manajemen@gmail.com

law in the hope that with this counseling they are able to understand religious knowledge and state law knowledge so that female students are able to apply zakat and waqf empowerment as well as positive law for themselves in particular and for society in general in the Alkamilah foundation in order to improve the people's economy.

The method of implementing this service is counseling and mentoring through a series of identification activities, assessments and a planned learning process with 3 stages, namely 1) Data collection, by providing interview data to female students about the understanding of zakat empowerment and productive waqf in terms of religious and legal studies. ). Training on zakat empowerment and productive waqf in terms of religious and legal studies by providing counseling to female students at the Al-kamilah foundation. 3) Providing training assistance on calculating zakat and productive waqf in terms of religious and legal studies. To support this, an activity plan is needed including the preparation stage, namely by preparing all the equipment needed to carry out PKM activities, studying literature and coordinating with related foundation agencies and the head of the foundation in particular. The stage of determining the location, namely by visiting the location. Design phase, implementation and supervision through sharia marketing training conducted by 5 lecturers at Pamulang University, Faculty of Economics, Accounting Study Program, to students at the Alkamilah Sawangan Foundation, Depok

The conclusion of this service is that the service participants are very enthusiastic about the training, this is shown by the many enthusiastic questions about zakat and waqf, both the calculation and processing of zakat and waqf, as well as legal studies.

\section{Keywords: Zakat, Waqf, Religion, Law, Social, Economy}

\section{PENDAHULUAN}

Zakat merupakan salah satu rukun Islam yang bercorak sosial-ekonomi

dari lima rukun Islam (Qardawi, 2007:3). Menunaikan zakat merupakan kewajiban bagi umat yang mampu sesuai dengan syariat Islam. Orang - orang Islam sangat mempercayai dan meyakini bahwa zakat merupakan salah satu dari pilar agama Islam yang bertujuan untuk meningkatkan keadilan, kesejahteraan masyarakat, dan penanggulangan kemiskinan. Kebanyakan orang Islampun berkeyakinan bahwa zakat mempunyai peran yang sangat penting dalam pemberdayaan ekonomi umat. Zakat juga merupakan salah satu rukun Islam yang selalu disebutkan sejajar dengan shalat. Inilah yang menunjukkan betapa pentingnya zakat sebagai salah satu rukun Islam (AlBa'ly, 2006:1). Untuk memaksimal pengelolaan zakat, infaq, shodaqoh dan wakaf, maka pemerintah membentuk badan yang mengelola dana zakat, infaq, shodaqoh dan wakaf yaitu Badan Amil Zakat (BAZ) yang dibentuk olen pemerintah dan Lembaga Amil Zakat (LAZ) yang dibentuk oleh masyarakat kemudian dikukuhkan oleh pemerintah.
Dalam hal ini lembaga zakat berfungsi untuk melakukan pencatatan dan pelaporan atas penerimaan dan pengalokasian zakat.

Pengelolaan zakat di Indonesia telah diatur dalam UU No. 38/1999 tentang pengelolaan zakat yang didalamnya mengatur segala kegiatan yang berhubungan dengan pengorganisasian, perencanaan, pelaksanaan, dan pengawasan terhadap pengumpulan serta pendistribusian serta pendayagunaan terhadap dana zakat. Keberadaan lembaga zakat merupakan suatu hal sangat penting seperti yang tertulis dalam pasal 5 Undang - Undang Republik Indonesia No 38 Tahun 1999 yaitu pengelolaan zakat bertujuan untuk meningkatkan pelayanan bagi masyarakat dalam menunaikan zakat sesuai dengan tuntunan agama, meningkatkan fungsi dan peranan pranata keagamaan dalam upaya mewujudkan kesejahteraan masyarakat dan keadilan sosial, serta meningkatkan hasil guna dan daya guna zakat (Mus.ab, 2011:2). Pada Undang - Undang No. 23 Tahun 2011 tentang pengelolaan zakat menyatakan pada pasal 1 point 7 bahwa Badan Amil Zakat Nasional yang selanjutnya disebut BAZNAS adalah lembaga yang melakukan 


\section{Loyalitas Kreativitas \\ Aldi Masyarakat Kreatif}

pengelolaan zakat secara nasional. Sedangkan pada point 8 disebutkan bahwa Lembaga Amil Zakat yang selanjutnya disingkat LAZ adalah lembaga yang dibentuk masyarakat yang memiliki tugas membantu pengumpulan, pendistribusian, dan pendayagunaan zakat.

Penerapan pengelolaan zakat produktif ini bukan berarti tanpa hambatan dan kendala. Pada praktiknya di lapangan banyak ditemukan kendala dan permasalahan. Mulai dari kendala pengumpulan dana zakat dari muzakki hingga pendistribusian serta pembinaan dan pendampingan sering kali terdapat masalah. Adapun faktor kendala yang dihadapi LAZ ada dua, yaitu faktor internal dan eksternal. Dari sinilah perlu adanya sosialisasi tentang pengetahuan pemberdayaan zakat dan wakaf produktif dalam kajian ekonomi syariah dan hukum positif dalam meningkatkan ekonomi umat bagi khususnya santriwan dan santriwati di yayasan Al-kamilah.

Saat ini, telah berdiri sebuah yayasan sosial di J1. Serua Raya No.3, Serua, Kec. Bojongsari, Kota Depok. Yayasan ini bernama AlKamilah, yayasan ini berdiri sejak 30 Oktober 2012 yang telah mampu menampung 30 anak asuh di asrama depok. Sedangkan 50 anak diantaranya berada Kebumen, Purwakarta, dan Banten. Melihat permasalahan tersebut, sangatlah penting memberikan penyuluhan tentang zakat dan wakaf kepada masyarakat khususnya santriwan santriwatidi yayasan Alkamilah, sekaligus sebagai wujud Tri Darma Perguruan Tinggi, Fakultas Ekonomi S1 UNPAM , maka diselenggarakanlah kegiatan pengabdian kepada masyarakat dengan judul "Pemberdayaan Zakat dan Wakaf Produktif dalam Kajian Ekonomi Syariah Dan Hukum Positif Dalam meningkatkan Ekonomi Umat"

\section{RUMUSAN MASALAH}

Dengan memperhatikan latar belakang yang telah dipaparkan diatas perumusan masalah pada PKM ini adalah : 1. Bagaimana memberikan penyuluhan tentang zakat dan wakaf produktif dalam Sudut kajian ekonomi syariah dan hukum positif pada santriwan santriwati di Al-Kamilah ?

2. Bagaimana memberikan penyuluhan pada santriwan dan santriwati tentang Pemberdayaan Zakat dan Wakaf Produktif?

3. Bagaimana memberikan penyuluhan tentang pemberdayaan zakat dan wakaf produktif dalam kajian ekonomi syariah dan hukum positif dalam meningkatkan ekonomi umat?

\section{TUJUAN KEGIATAN}

Kegiatan pelatihan ini diharapkan mampu memberikan dampak jangka panjang bagi santriwan-santriwati yayasan Al-Kamilah sebagai berikut :

1. Membantu santriwan dan santriwati di yayasan Alkamilah dalam memahami sakat dan wakaf produktif dalam sudut kajian ekonomi syariah dan hukum positif.

2. Memberikan wawasan kepada santriwan santriwati di yayasan Alkamilah tentang bagaimana memberdayakan zakat dan wakaf produktif pada masyaraka.

3. Memberikan penyuluhan tentang pemberdayaan zakat dan wakaf produktif dalam kajian ekonomi syariah dan hukum positif dalam meningkatkan ekonomi umat

\section{TINJAUAN PUSTAKA \\ Zakat dan Wakaf}

Zakat merupakan salah satu pilar (rukun) dari lima pilar yang membentuk Islam. Zakat adalah ibadah maaliah ijtima'iyyah yang memiliki posisi yang strategis dan menentukan bagi pembangunan kesejahteraan umat (Huda, 2015: 5). Sehingga zakat tidak hanya berfungsi sebagai ibadah yang bersifat vertikal kepada Allah, namun zakat juga berfungsi sebagai wujud ibadah yang bersifat horizontal.

Di Indonesi yang mayoritas penduduknya bergama Islam sebenarnya memiliki potensi yang strategis dan sangat layak untuk dikembangkan dalam menggerakkan perekonomian negara. Selain itu, konsep zakat yang ditawarkan 


\section{Loyalitas Kreativitas \\ Aldi Masyarakat Kreatif}

Islam menjanjikan dimensi kemaslahatan dan pengelolaan potensi sumber daya ekonomi dalam kehidupa masyarakat.Pendekatan transformatif dalam pengembangan ekonomi Islam melalui gerakan zakat sebagai gerakan ekonomi yang berlandaskan syari'ah Islam, merupakan aktualisasi operasional ekonomi Islam dalam mewujudkan kesejahteraan masyarakat. Zakat merupakan wujud pilar perekonomian Islam dalam menjalankan fungsinya untuk mengelola dan menyalurkan dana umat kepada orang-orang yang berhak. Hal yang sering dipertimbangkan di tengah masyarakat kita adalah kepada siapa zakat harus diberikan. Lebih utama disalurkan langsung oleh muzakki kepada mustahiq, atau sebaliknya melalui amil zakat. Jika disalurkan kepada mustahiq, memang ada perasaan tenang karena menyaksikan secara langsung zakatnnya tersebut telah disalurkan kepada mereka yang dianggap berhak menerimanya. Tapi terkadang penyaluran langsung yang dilakukan oleh muzakki tidak mengenai sasaran yang tepat.

Terkadang orang sudah merasa menyalurkan zakat kepada mustahiq, padahal ternyata yang menerimanya bukan mustahiq yang sesungguhnya, seperti hanya karena kedekatan emosi maka ia memberikan zakat kepadanya. Oleh karena itu, untuk menyalurkan zakat dari muzakki untuk mustahiq diperlukan lembaga penyaluran zakat yang mempunyai tugas khusus menjadi amil zakat yakni mengalokasikan, mendayagunakan, mengatur masalah zakat, baik pengambilan maupun pendistribusiannya (Sanihah, 2014: 3).

\section{Zakat dan Wakaf menurut Hukum}

Menurut UU No. 23 tahun 23

Tahun 2011 tentang pengelolaan zakat, zakat adalah harta yang wajib dikeluarkan oleh seorang muslim atau badan usaha untuk diberikan kepada yang berhak menerimanya sesuai dengan syariat Islam.

Mathews and Tlemsani dalam Dogarawa menyebutkan zakat merupakan bagian tertentu dari kekayaan yang ditentukan oleh Allah untuk didistribusikan kepada kategori orang yang berhak menerimanya. Ini diwajibkannya kepada orang yang memiliki kelebihan harta kepada orang yang kekurangan harta.

Undang-Undang Republik

Indonesia No. 41 tahun 2004 tentang Wakaf dan PP No 42/2006, diarahkan untuk memberdayakan wakaf yang merupakan salah satu instrumen dalam membangun kehidupan sosial ekonomi umat Islam. Kehadiran Undang-undang wakaf ini menjadi momentum pemberdayaan wakaf secara produktif serta perluasan pemaknaan obyek wakaf, sebab di dalamnya terkandung pemahaman yang komprehensif dan pola manajemen zakat secara modern.

\section{METODE PELAKSANAAN}

Langkah-langkah yang dilakukan untuk mencapai tujuan dan sasaran kegiatan ini adalah:

1. Tahap Persiapan

Tahap persiapan yang dilakukan meliputi :

1) Survei awal, Pada tahap ini dilakukan survei lokasi Yayasan Alkamilah di Desa Serua, Kec. Bojongsari Kab. Depok JawaBarat.

2) Observasi. Setelah survei maka ditentukan pelaksanaan dan sasaran peserta kegiatan

3) Rapat Koordinasi Tim. Pada tahap ini rapat mengenai pembagian tugas, membuat jadwal pelaksanaan, mulai dari persiapan, pelaksanaan, sampai evaluasi dan penyusunan laporan.

2.Tahap Evaluasi

Tahap evaluasi merupakan penilaian setelah rangkaian kegiatan dilakukan oleh pelaksana sesuai dengan jadwal yang telah ditentukan. Evaluasi ini bisa berupa perbaikan atau saran untuk pelaksanaan kegiatan lebih baik lagi dan kelanjutan menjadi binaan kampus.

a. Partisipasi Mitra dalam Pelaksanaan Program

Partisipasi mitra dalam pelaksanaan program PKM ini sangat kooperatif dengan memberikan ijin kepada tim untuk melaksanaankan pengabdian desa binaan kampus, memberikan keterangan baik berupa informasi atau data-data yang dibutuhkan sampai rencana 


\section{Loyalitas Kreativitas \\ Aldi Masyarakat Kreatif}

P-ISSN 2722-2101, E-ISSN 2722-4201

Program Studi Ekonomi Manajemen Universitas Pamulang

Jurnal LOKABMAS Kreatif Vol.02,No.03.Nov2021Hal.8-13

Email:jurnalkreatif.manajemen@gmail.com pelaksanaan berupa kegiatan pelatihan/pendampingan nantinya.

b. Realisasi Pemecahan Masalah

Realisasi pemecahan masalah dalam Pengabdian Kepada Santriwati Santriwan yayasan Al Kamilah ini, menghasilkan beberapa hal yang dapat di laksanakan oleh para dosen antara lain:

1) Untuk pengabdian selanjutnya adalah membuat rumah baca tentang buku buku kesyariahan zakat dan wakaf dalam upaya meningkatkan kecerdasan agar mudah terimplementasi nya pemahaman tentang pemberdayaan zakat dan wakaf produktif dalam kajian ekonomi syariah dan hukum di yayasan Alkamilah.

2) Melaksanakan pendampingan dengan memberikan penyuluhan terhadap Santriwan Santrwati dalam upaya untuk pemberdayaan zakat dan wakaf di yayasan Alkamilah serua depok JawaBarat.

\section{c. Khalayak Sasaran}

Khalayak sasaran dalam Pengabdian Kepada Msyarakat ini adalah seluruh Santriwan Santriwati di Yayasan Alkamilah Serua depok Jawa barat.

Dengan adanya Penyuluhan tersebut diharapkan nantinya Santriwan dan santriwati mampu menerapkan pengelolaan zakat dan wakaf baik bagi diri khususnya dan bagi masyarakat umumnya di yayasan Alkamilah Serua depok Jawa barat.

\section{HASIL DAN PEMBAHASAN Hasil Kegiatan}

Berikut ini secara ringkas pembahasan dan kegiatan pengabdian masyarakat yang telah dilakukan pada $24 \mathrm{~s} / \mathrm{d}$ 26 Mei 2021 adalah:

1. Acara dibuka dihari pertama dengan Pembukaan PKM dengan pembacaan Ummul AlQuraan bersama sama, dimana pada saat ini diberikan berbagai macam sambutan, baik dari pihak Yayasan Alkamilah maupun dari pihak UNPAM. Setelah itu, acara dilanjutkan didalam ruangan dengan memberikan pembekalan materi kepada para peserta PKM yang terdiri dari para guru-guru yayasan dan santriwan-santriwati Yayasan Al-Kamilah Depok Jawa Barat.

2. Materi diberikan oleh narasumber satu membahas tentang zakat dihari pertama dan wakaf produktif dihari kedua, Dimana zakat dan wakaf produktif harus diatur sedemikian rupa, sehingga jangan sampai sasaran dari progam tidak tercapai. Pengelolaan dana zakat produktif, pendistribusiannya pihak BAZNAS memperhatikan orang-orang yang akan menerimanya, apakah dia termasuk orang-orang yang berhak menerima zakat dari golongan fakir miskin, demikian juga termasuk orangorang yang mempunyai keinginan kuat untuk bekerja dan berusaha. Kaitannya dengan zakat produktif, proses tersebut harus meliputi perencanaan, pengorganisasian, penggerakan dan pengawasan. "Tidak boleh membahayakan diri sendiri dan tidak boleh memberi bahaya (mudarat) kepada orang lain." (HR Ahmad, Ibnu Majah).

3. Materi dihari ketiga diutarakan oleh narasumber yang kedua membahas zakat dan wakaf dalam kajian hukum positif guna meningkatkan ekonomi umat. Dimana dalam Wakaf Produktif Kementerian Agama untuk lebih mensosialisasikan UU No. 41 Tahun 2004 dan Peraturan Pemerintah No. 42 Tahun 2006 tentang Wakaf kepada masyarakat khususnya para nazhir. Agar nazhir bekerja profesional dan kreatif mengembangkan wakaf baru, maka nazhir sebaiknya mendapatkan $10 \%$ dari keuntungan pengelolaan wakaf seperti yang tercantum dalam UU No. 41 Tahun 2004. Ada beberapa hal yang perlu nazhir lakukan dalam pengelolaan wakaf diantaranya Yaitu :Laporan keuangan yang sistematis dan kinerja yang berbasis komputerisasi.

Setelah semua materi diutarakan, maka dilakukan quis dan permainanpermainan dengan memberikan pertanyaan pertanyaan dengan memberikan hadiah kuis baik yang 


\section{Loyalitas Kreativitas \\ Aledi Masyarakat Kreatif}

P-ISSN 2722-2101, E-ISSN 2722-4201

Program Studi Ekonomi Manajemen Universitas Pamulang Jurnal LOKABMAS Kreatif Vol.02,No.03.Nov2021Hal.8-13

Email:jurnalkreatif.manajemen@gmail.com bertanya maupun yang menjawab. Tujuannya adalah untuk menguji pemahaman peserta mengenai materi yang sudah diberikan.

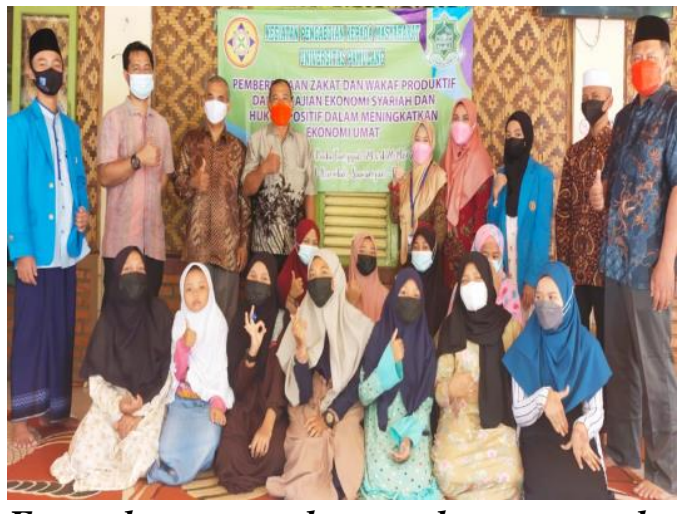

Foto bersama dosen dan perangkat yayasan Al Kamilah

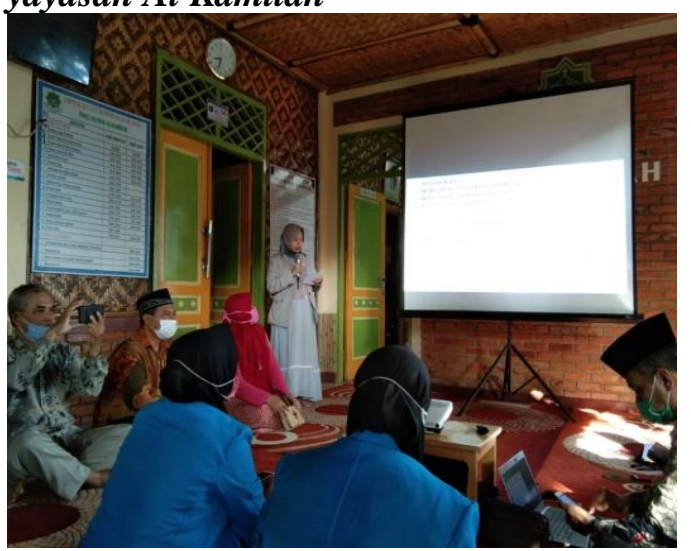

Pembukaan Kegiatan PKM di yayasan AlKamilah

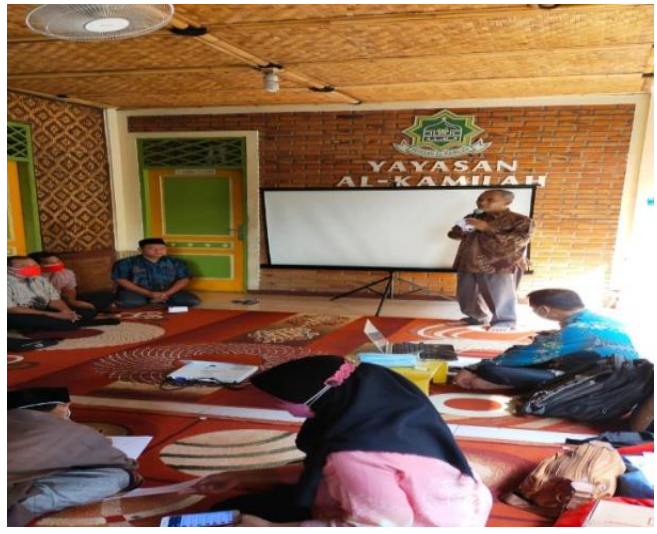

Sambutan Ketua PKM

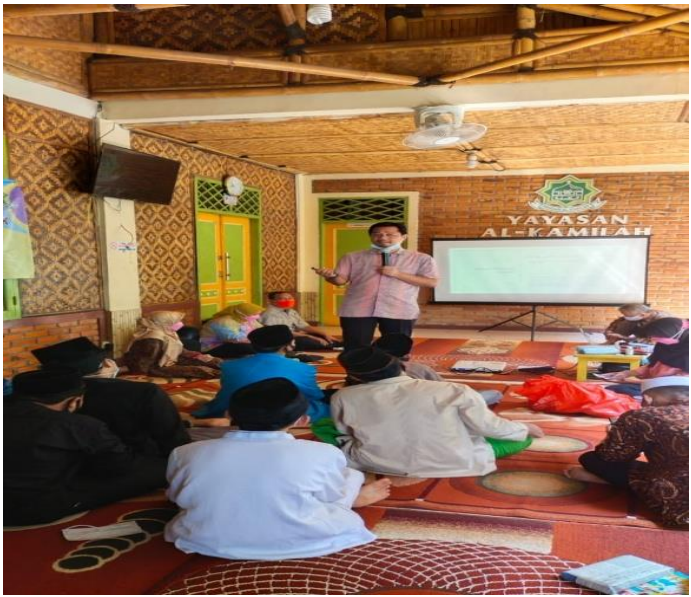

Pemaparan Narasumber 1(Zakat dan wakaf dalam kajian agama)

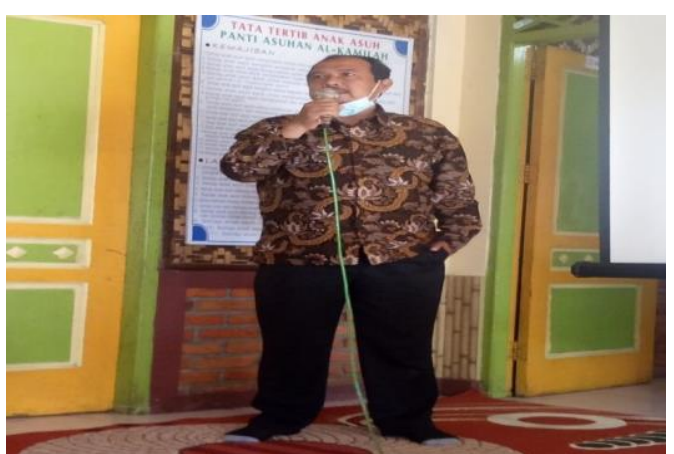

Pemaparan Narasumber 2(Zakat dan Wakaf dalam kajian hukum positif)

\section{KESIMPULAN DAN SARAN \\ Kesimpulan}

Kesimpulan dari pengabdian ini adalah: Pengabdian Kepada Masyarakat di yayasan Al-Kamilah tentang zakat dan wakaf kajian ekonomi syariah dan hukum positif dalam meningkatkan ekonomi umat berjalan lancar, peserta pengabdian sangat antusias terhadap pelatihan, hal ini ditunjukan dengan banyaknya antusiasme pertanyaan tentang zakat dan wakaf, baik penghitungan dan pengolahan zakat dan wakaf, serta kajian hukumnya

\section{Saran}

Berdasarkan hasil kegiatan PKM yang sudah dilakukan, maka kami dari team Dosen Universitas Pamulang memberikan saran yaitu Agar Pengabdian masyarakat selanjutnya bisa mewujudkan Rumah baca yang 


\section{Loyalitas Kreativitas \\ Aldi Masyarakat Kreatif}

P-ISSN 2722-2101, E-ISSN 2722-4201

Program Studi Ekonomi Manajemen Universitas Pamulang Jurnal LOKABMAS Kreatif Vol.02,No.03.Nov2021Hal.8-13

Email:jurnalkreatif.manajemen@gmail.com berhubungan dengan Kajian Agama dan Hukum Positif tentang zakat dan wakaf produktif guna memberikan kemudahan fasilitas santriwan santriwati untuk bisa lebih mudah mengakses pengetahuan tentang kajian Agama dan Hukum Positif guna meningkatkan ekonomi umat.

\section{DAFTAR PUSTAKA}

Abdul Al-Hamid Mahmud AlBa'ly.Ekonomi Zakat : Sebuah Kajian Moneter dan Keuangan Syariah. Jakarta: PT. Raja Grafindo Persada, 2006

Achmad Syaiful Hidayat Anwar, Model Pemberdayaan Ekonomi Mustahiq Melalui Zakat, JEAM Vol. XV, 2016

Al-Qardhawi, Yusuf. Hukum Zakat. Bogor: Litera Antar Nusa. 1999.

Al-Qur'an Al-Karim dan Terjemahan, Lembaga Percetakan Al-Qur'an Raja Fahd

Arief Mufraini, Akuntansi dan Manajemen Zakat, Kencana Prenada Media Group, Jakarta, 2006.

Djunaidi, Achmad, Al Asyhar, Thobieb, Menuju Era Wakaf Produktif Sebagai Upaya Progresif untuk Kesejahteraan Umat, Mitra Abadi Press, Jakarta, 2005.

Musahadi HAM, Evolusi Konsep Sunnah; Implikasinya pada Perkembangan Hukum Islam, (Semarang: Aneka Ilmu, 2000).

UU No. 38/1999 tentang pengelolaan zakat

Undang - Undang No. 23 Tahun 2011 tentang pengelolaan zakat

UU No. 41 Tahun 2004 tentang pengelolaan wakaf
Pasaribu, V. L. D., Agrasadya, A., Shabrina, N., \& Krisnaldy, K. (2020). Menjadi Enterpreneur Muda Yang Memiliki Jiwa Leadership Untuk Menghadapi Masa Depan. Abdi Laksana: Jurnal Pengabdian Kepada Masyarakat, 1(1).

Pasaribu, V. L. D., Susanti, F., \& Hartuti, E. T. K. (2019). Memotivasi Siswa dan Siswi SMK Letris Indonesia di Dalam Menentukan Pilihan Untuk Melanjutkan Pendidikan Atau Bekerja Setelah Lulus Sekolah. Jurnal Pengabdian Dharma Laksana, 1(2), 161-172.

Pasaribu, V. L. D., Sulaiman, S., Sutiman, S., Thaharudin, T., \& Purnomo, B. Y. (2020). Pengenalan Letak Posyandu Terdekat Dikelurahan Pisangan Dengan Manajemen Pemasaran Revolusi 4.0 Untuk Meningkatkan Pengetahuan Masyarakat Letak Dan Fungsi Posyandu Terdekat Pada Kelurahan Pisangan. Dedikasi Pkm, 1(1), 105110.

Pasaribu, V. L. D., Oktrima, B., Prabowo, B., Arianto, N., \& Haryoko, U. B. (2020). Progam Pendampingan Dan Penyelenggaraan Pendidikan Anak Pada Usia Dini Terhadap Prestasi Belajar Dilingkungan Rt $020 \mathrm{Rw}$ 009. Kel Giri Peni. Kec Wates. Yogyakarta. Jurnal Lokabmas Kreatif, 1(1), 71-75.

Pasaribu, V. L. D., Jannah, M., Fazar, M., Putra, S. P., Monalisa, M., \& Sofa, M. (2021). MENINGKATKAN PRODUKTIVITAS USAHA DIMASA PANDEMI PADA IBU PKK RT 004/003 KELURAHAN SAWAH BARU CIPUTAT, TANGERANG SELATAN. Abdi Laksana: Jurnal Pengabdian Kepada Masyarakat, 2(2), 295301.

Pasaribu, V. L. D., Yuniati, H. L., Pranata, R., Sembayu, R., Purba, S. M., \& 


\section{Loyalitas Kreativitas \\ Aldi Masyarakat Kreatif}

P-ISSN 2722-2101, E-ISSN 2722-4201

Program Studi Ekonomi Manajemen Universitas Pamulang Jurnal LOKABMAS Kreatif Vol.02,No.03.Nov2021Hal.8-13

Email:jurnalkreatif.manajemen@gmail.com
Nurbayani, T. T. A. (2021). MANAJEMEN KEUANGAN UNTUK MENGHADAPI DAN BERTAHAN DI ERA COVID 19. Jurnal Abdimas Tri Dharma Manajemen, 2(2), 12-18.

Pasaribu, V. L. D., Dwiyatni, A., Sabina, C., Ridwan, M., Gunawan, D. D., \& Noviani, B. C. (2021). EVALUASI PENERAPAN 3M DIMASA PANDEMIC COVID 19. Jurnal Abdimas Tri Dharma Manajemen, 2(2), 54-60.

Pasaribu, V. L. D., Syafei, A. N., Farhan, A., Aufaizah, A., Irani, C., \& Firtiayani, S. R. (2021). PENGARUH DISPLIN PROTOKOL KESEHATAN TERHADAP PENCEGAHAN PENULARAN VIRUS COVID19. Jurnal Abdimas Tri Dharma Manajemen, 2(2), 91-98.

Pasaribu, V. L. D., Septiani, F., Rahayu, S., Lismiatun, L., Arief, M., Juanda, A., ... \& Rahim, R. (2021). Forecast Analysis of Gross Regional Domestic Product based on the Linear Regression Algorithm Technique.
Pasaribu, V. L. D., Priadi, A., Anismadiyah, V., Rahayu, S., \& Maduningtias, L. (2021). PENYULUHAN KREATIF DAN INOVATIF MENINGKATKAN MUTU PRODUKSI UMKM DI DESA BELEGA KABUPATEN GIANYAR. Pro Bono Jurnal Pengabdian Kepada Masyarakat, 1(02).

Pasaribu, V. L. D. (2021). PELATIHAN BERBASIS ONLINE DI ERA COVID19. Jurnal Abdimas Tri Dharma Manajemen, 2(3), 26-32.

Pasaribu, V. L. D., \& Setyowati, R. (2021). ADAPTASI KEHIDUPAN NEW NORMAL PADA MASA PANDEMI COVID-19 DIYAYASAN PONDOK PESANTREN DAN PANTI ASUHAN NURUL IKHSAN KECAMATAN SETU, KOTA TANGERANG SELATAN. Jurnal Lokabmas Kreatif: Loyalitas Kreatifitas Abdi Masyarakat Kreatif, 2(2), 82-88.

Priadi, A., Pasaribu, V. L. D., Virby, S., Sairin, S., \& Wardani, W. G. (2020). Penguatan Ekonomi Kreatif Berbasis Sumber Daya Desa Dikelurahan Rempoa. Abdi Laksana: Jurnal Pengabdian Kepada Masyarakat, 1(3), 356-35 